\title{
Modern Directions of Forensic Experts Primary Training
}

\author{
Oksana G. D'iakonova* \\ Kutafin Moscow State University \\ Moscow, Russia Federation
}

Received 03.02.2020, received in revised form 31.08.2020, accepted 05.10.2020

\begin{abstract}
No type of legal proceedings is complete without the involvement of experts for the production of expert research or specialists for consultation. In this regard, the question of determining the competence of these subjects by persons conducting the process who do not have special knowledge in the field in which the knowledgeable person specializes is very acute. The author determines the competence of the forensic expert and enumerates other requirements to the expert as a participant in the proceedings. The formation of competence is primarily influenced by the level of training, education of an expert or specialist. The main attention focuses on the disclosure of the main ways of initial training and retraining of forensic experts at the present stage: the traditional way of experts training; specialization in the specialty "Forensic examination"; master's degree in programs of expert specialties. The existing types of training and retraining of forensic experts in Russia and some foreign countries, including the member States of the Eurasian economic Union (EEU), are analyzed. The traditional way of training of forensic experts and training under the program of specialization are revealed proceeding from historical conditionality and necessity of training of specialists for implementation of forensic activity. The positive and negative features of the training areas are highlighted, taking into account their impact on the formation of the competence of the forensic expert. The author emphasizes the need to develop existing forms of initial training of forensic experts, taking into account the advantages and disadvantages of each of them. The study concludes that it is necessary to apply the subjective criterion in order to determine the effective form of training of forensic experts.
\end{abstract}

Keywords: training of experts, retraining of experts, higher education, forensic examination, use of special knowledge.

Research area: criminalistics, forensic activity, operational-search activity.

Citation: D'iakonova, O.G. (2020). Modern directions of forensic experts primary training. J. Sib. Fed. Univ. Humanit. Soc. Sci., 13(10), 1662-1670. DOI: 10.17516/1997-1370-0672.

\footnotetext{
(C) Siberian Federal University. All rights reserved

* Corresponding author E-mail address: oxana_diakonova@mail.ru ORCID: 0000-0002-9327-5585
} 


\section{Introduction}

Judicial proceedings as the jurisdictional activity of the courts in the consideration and resolution of various categories (criminal, civil, administrative) cases from the moment of its inception did not do without using special knowledge, without involving knowledgeable people in the case. The use of special knowledge in various forms is now widespread, almost no criminal and rare civil cases are dispensed without a forensic examination or specialist advice. In this article, the terms "expert" and "specialist" are not understood to mean posts, but participants in legal proceedings having a procedural legal status and participating in special forms: an expert - for conducting a forensic examination, a specialist - for giving advice. Therefore, when it comes to the educational training of these persons, we mean the training of forensic experts as specialists in a certain field of science, technology, art, etc., having the right to participate in legal proceedings as a forensic expert and (or) specialist. Speaking in legal proceedings, experts and (or) specialists are able to provide serious assistance to both persons conducting legal proceedings and other participants in the process. "An expert is a participant in a process disinterested in the outcome of the process, possessing special knowledge, who is involved in order to conduct research on the objects presented and to give an opinion on the questions posed to him by the person (body) conducting the process, responsible for the conclusions drawn. A specialist is a participant in the process who has special knowledge, is not interested in the outcome of the case and is involved in legal proceedings or other jurisdictional activities to assist the person (body) conducting the process, in order to provide advice, clarifications, assist in the investigation of evidence, and provide scientific technical assistance and the use of scientific and technical means, responsible for the consultation provided" (D'iakonova, 2019: 58, 68).

Qualitatively identifying a competent expert for an examination or a specialist for consultation is really difficult. Even 20-30 years ago, the question of the appointment and conduct of forensic examination in a particular organization had a slightly different sound than now. Basically, there were state forensic institutions within specific departments that conducted forensic examinations according to their approved methods, which had the necessary material and technical support, and were responsible for the advanced training of a forensic expert and the quality of research. Now, among the array of offers available to the user for a search query on the production of a forensic examination of a particular type, it is rather difficult to figure it out on the wide expanses of the Internet. This is especially true in connection with the determination of the cost of conducting a forensic examination, because the person who pays for the study wants to save money. Therefore, the question of the quality of the research is raised whenever a user is forced to look for an expert organization or an expert who is able to conduct an appropriate study on time and at an appropriate cost. The main criterion for such an ability is, of course, the expert's competence, which is simply impossible to assess according to the website of an expert organization or a private expert. However, the decision on the issue of competence directly depends on the expert training system, on a unified approach to it, which could serve as the general criterion that distinguishes competent judicial experts from other persons who want to earn extra money due to their ignorance of other persons.

1. Competence and other requirements for the expert. The competence of a forensic expert, as well as a specialist, that is, all knowledgeable individuals as a whole, is formed first in the process of his educational preparation, and later on in his work, with the accumulation of experience. Taking into account the expert approach (which is applied within the framework of the science of forensic science), "the competence of a competent person is a subjective characteristic that reflects the amount of knowledge, practical skills, abilities, experience, personal qualities of a specific competent person obtained in the preparation process , training, professional development, in one or several areas of special knowledge and applied by him in the implementation of professional activities" (D'iakonova, 2019: 48). In contrast to competence, "the competence of an expe- 
rienced person is an objective characteristic that reflects the objectively existing amount of knowledge, techniques, practical skills inherent in a particular area of special knowledge that an experienced person must acquire in the process of preparation, training, advanced training, and limited by the current level of development of this areas" (D'iakonova, 2019: 48). The competence of the knowledgeable person in the broad sense also includes his powers, defined by the procedural law, contributing to the fulfillment by him of his procedural function.

In addition to competence, the expert should be disinterested in the outcome of the case, meet the requirements of professional ethics and morality (Mailis, 2018: 52), provided that an expert in the position is called in as the leading person, as well as his involvement in the proceedings and other jurisdictional activities should be carried out in the forms specified in the relevant legislation. All of these requirements are interrelated with the requirement of expert competence, one way or another, are based on his preparation for the implementation of the function to apply special knowledge.

Among the normative legal acts defining these requirements, it should be noted: procedural codes (Code of Criminal Procedure, agribusiness of the Russian Federation, Code of Administrative Offenses of the Russian Federation, Code of Civil Procedure of the Russian Federation, Code of administrative procedure of the Russian Federation), Federal Law "On State Forensic Science Activities in the Russian Federation", Federal Law "On Education in Russian Federation" and Orders of the Ministry of Education and Science, for example, «On the approval of the federal state educational standard of higher education in the specialty 40.05.03 "Forensic examination" (level of specialty)".

2. Training of forensic experts in foreign countries and Russia. In Russia today, there are several ways and forms of obtaining knowledge that allow subjects to subsequently act in court proceedings as a competent person. So, a person who has received a basic higher education in any field of special knowledge, for example, economics, engineering, chemis- try, physics, with subsequent retraining in an expert institution and obtaining a qualification certificate for the right to conduct examinations of a certain kind (type) can become a forensic expert; or by obtaining the specialty 40.05 .03 "Forensic Expertise"; or through the training of forensic experts as part of master's programs.

A number of EEU participating countries have a similar system of training forensic experts. For example, in Belarus, a university graduate who has studied in the legal, medical, economic, and technical fields may become a forensic expert. Since 2003, in the Republic of Belarus, training and retraining of experts by the Institute for Advanced Studies and Retraining of Personnel of the State Committee of Forensic Expertise of the Republic of Belarus has been carried out (Grinkevich, 2017: 282). In addition, applicants can receive an education in the specialty of higher education of the first level "Forensic examinations" and qualify as "Forensic expert. Lawyer" (Lapina, 2018). In the Kyrgyz Republic, higher education in the specialty "Forensic Expertise" is carried out by universities, for example, Kyrgyz-Russian Slavic University. The Republic of Kazakhstan does not provide for obtaining a higher expert education in the specialty "Forensic Expertise" (Smol'kov, Paramonova, 2013: 265), only in the direction of training within the framework of undergraduate studies, but qualification training in the relevant expert specialty is carried out by the Center for Forensic Expertise of the Ministry of Justice of the Republic of Kazakhstan. In Lithuania, "the training of modern experts is carried out according to the programs of one of the oldest and strongest European schools, which has the deepest roots - the Russian school" (Tamoshiunaite, 2018: 117). Universities operate in the Republic of Armenia to prepare bachelors and masters in the field of "Forensics Expertise", for example, the Yerevan Institute of Forensics and Psychology.

A common feature of the training of experts in universities in the EAEU member countries is the placement of a specialty or area of study "Forensic Expertise" as part of the legal area of training. This feature is distinctive from many foreign countries, where the training of forensic experts is carried out on 
the basis of other specialties, as a rule, natural sciences. So, in the United States provides multilevel education for work in various forensic laboratories. For example, "to work in a forensic laboratory in rural areas, forensic specialists need a high school diploma; to work in a forensic laboratory of a larger law enforcement agency, a bachelor's degree (college level) in forensics or science, such as biology or chemistry. At the same time, training in the police academy is being carried out in some areas of forensics" (Alyson). Further training is provided. However, in the United States there is a tendency to increase the level of education of experts, at least at the academic undergraduate level in a scientific specialty (U.S. Department of Justice...), but not within the legal framework. D. Alison predicts an increase in interest in this profession and emphasizes, "taking into account a number of reasons, for example, awareness among potential jurors of judicial evidence in criminal cases, increased competition, which will lead to professionals with a bachelor's degree in forensic science or related areas will have an advantage over graduates in employment" (Alyson). For a number of expert specialties, American universities provide training for a short period of time, including distance learning programs (Moiseeva, 2019: 424).

3. The traditional way of training forensic experts is the retraining of specialists of other specialties for the needs of forensic activities. The training of forensic experts in both pre-revolutionary Russia and the post-revolutionary period was reduced mainly to the acquisition by persons with certain knowledge in any scientific field of legal orientation, but in a very concise form, on the basis of state forensic institutions. It was not about full systemic training. As a rule, this was fragmentary information about the forms of participation in legal proceedings, the rights, duties and responsibilities of experts, the basics of forensic science. Basically, such forensic experts gained such knowledge, although training was also carried out in other specialties, for example, forensic photography and photographic equipment. It should be noted that at that time the involvement of experts of other specialties only became the rule, rather, it looked like an exception to it. Over time, the training of specialists began to be carried out as part of advanced training courses for forensic chemists, forensic specialists in criminal investigation, who come to work in bodies mainly with secondary specialized education. Since 1923, police schools began training forensic specialists in Moscow, Leningrad, Samara, Orenburg and other cities.

Subsequently, in the Soviet period, the participation of experts and specialists in criminal, and later in civil proceedings, began to take on a universal character. The need for more specialists able to provide scientific, technical and consulting assistance and expert research has increased. However, to receive a full comprehensive education was still far away. The training of experts was mainly carried out as follows: a specialist who gained knowledge in any scientific field, such as chemistry, physics, engineering, came to work in the expert service of the internal affairs bodies, underwent retraining for a certain period of time, mainly up to a year. At the end of the training, he received a qualification certificate for the right to conduct examinations of a certain kind (type). Then he started to work first under the guidance of an experienced mentor - a forensic expert, and subsequently on his own. The obvious minus of this way of training experts was the time period during which the person was qualified as a forensic expert.

In general, the traditional way of training forensic experts, in the absence of other alternatives, to some extent coped with the situation of a shortage of qualified personnel. However, a serious omission was the lack of in-depth legal knowledge of procedural law, criminalistics, forensic science, and other disciplines: criminal, civil, and labor, the knowledge of which is really necessary for a forensic expert to properly carry out his activities. As correctly writes E.R. Rossinskaya, "the training of forensic experts is not a mechanical combination of two legal and other formations, but a complex integrative education that allows you to form the necessary competencies, while separately two educations plus continuing education courses do not allow you to form the necessary professional competencies, form expert thinking" 
(Rossinskaya, 2018: 79). Unfortunately, the traditional way of training forensic experts does not take into account the level of development of science, including the science of forensic science - forensic expertology.

However, one of the areas in which the traditional path was transformed was the training of specialists, both already working experts and non-experts, in the programs of further professional education. Successful experience in such training is shared by the Russian Federal Center for Forensic Expertise of the Ministry of Justice of Russia, which has developed its own strategy for implementing the DPO system for expert specialties (Toropova, 2017: 20). It seems that the system of retraining of experts may be well implemented not only in expert organizations that have received a license to provide educational services, but also by universities that train experts.

4. Specialty training "Forensic Expertise". For the first time, future experts with higher education in the RSFSR began to be trained at the Higher Investigative School of the Ministry of Internal Affairs of the USSR (now the Volgograd Academy of the Ministry of Internal Affairs of Russia) and subsequently at other universities of the Ministry of Internal Affairs system. In addition to Soviet citizens, foreigners were trained in this area of training. Trainees in this specialty received a certificate for the right to produce a number of forensic examinations. This situation lasted until 1999, when several universities of the country, in addition to the Ministry of Internal Affairs of Russia, began to train specialists with higher education in the specialty 35060 "Forensic Expertise" with the qualification of "Expert Forensic Scientist". Since 2004, after the entry into force of the educational standard of the second generation, graduates of this specialty were assigned the qualification of "Judicial Expert". Since 2013, the specialty "Forensic Expertise" has been logically integrated into the group of specialties "Jurisprudence". Without a doubt, the adoption of the Federal State Educational Standard of Higher education "Forensic Expertise" the 3rd generation is progressive, although the authors pay attention to some points (Kaverina, 2019: 185), related to the identity of the provisions of the Federal State Educational Standard of Higher education "Forensic Expertise" and Federal State Educational Standard of Higher education in the direction of preparation 38.05.01 "Economic Security".

The literature has previously formulated the positive features of training within the framework of the specialty: "1) professional educators are engaged in the preparation of a specialist on the basis of an approved standard, as well as developed programs and teaching materials; 2) for five years, a student develops a set of competencies necessary for further professional activities such as: critical understanding of information, statement of research tasks; the ability to apply natural scientific and mathematical methods in solving professional problems, apply forensic research techniques in professional activities, and many others; 3) the future expert receives knowledge not only from the field of direct professional activity, but also of a legal nature: features of legal proceedings, operational investigative activity, psychology, etc.; 4) there is modern forensic equipment for training future experts; 5) students are involved in the scientific activities of the university within the framework of their chosen training program and participate in meetings of scientific circles, conferences, develop projects and so on; 6) it is possible to give students knowledge and skills from the field of natural sciences (chemistry, physics, biology, etc.). Despite the fact that in his future practice, the expert does not use this knowledge extensively, however, they allow to form a special type of thinking" (Ivanova, D’iakonova, 2018: 88).

However, negative points also occur. Firstly, insufficient staffing of universities. It seems desirable that the teachers of special disciplines were current experts with scientific degrees, which is not always possible. Since there are not so many specialists with proper work experience as universities that want to train experts, and, in addition, not all experts have the desire and opportunity to obtain a degree. Secondly, the insufficiently equipped educational institutions with laboratories and equipment for training in accordance with the Federal State Educational Standard of Economics. Financing of universities is conducted at a low level, al- 
though recently the situation has improved significantly, and students need to obtain not only theoretical knowledge, but also hone practical skills, which is impossible to do in conditions of unequipped premises. It should be noted that the universities included in the Association of Educational Institutions "Forensic Expertise" show a generally positive situation on the first two points.

Thirdly, the restriction of training in the specialty program to full-time only (clause 3.2 of the Federal State Educational Standard). It is not very clear on what basis the Federal State Educational Standard of Higher education "Forensic Expertise" forbids the preparation of forensic experts through full-time and part-time forms (evening education). It seems that this issue should be discussed and taken into account that training in the specializations indicated in the Federal State Educational Standard of Higher education "Forensic Expertise" can well be carried out using evening uniforms, provided that the university is able to provide staff and material and technical equipment for laboratories. This type of training in a number of expert specialties may well come to replace the traditional path - retraining specialists on the basis of expert institutions.

Of course, as N.S. Neretina notes, far from all specialties training is possible "within the framework of the first higher expert education. For example, the training of specialists in forensic medical, psychiatric, psychological, environmental examinations and some other types is carried out in the course of additional special training" (Neretina, 2017: 68). Although in this case, there is a need to bring the curriculum for preparing students of these specialties in line with the practical component, which implies the inclusion of a sufficient number of hours to study a number of legal, especially procedural, disciplines. Forensic experts of any specialty must understand not only the procedural foundations of a particular type of legal procedure in which they can be involved as a specialist or expert, but also clearly know the procedural legal status of these competent persons and understand how their rights and obligations are realized, what kind of guarantee implementations are established by law.
5. Master's degree in forensic specialty. It can be said that the traditional way of expert training has now transformed into this form. First, the student is trained in any direction of undergraduate level training. This is considered a basic education, as a rule, in natural sciences, technical areas, or in the field of economics, psychology, and jurisprudence. After receiving a bachelor's diploma, the student enters the magistracy under the program of training forensic experts.

One of the first educational programs for the training of experts in the framework of the magistracy appeared at the Kutafin Moscow State Law University (Moscow State Law Academy) - "Forensic expert support of law enforcement". In the subsequent "RUDN Law Institute, together with the Russian Federal center for forensic expertise of the Ministry of Justice of Russia - an educational project was prepared to implement the master's programs "Forensic Expertise in Law Enforcement"" (Usov, 2015: 23; Smirnova, 2018: 14).

As E.R. Rossinskaya writes, "the objectives of such master's programs are the fundamental training of Masters of Law in the field of professional legal activity, having professional competencies in the use of special knowledge ... In this form, it is possible to train experts only in certain separate genders, and not in forensic classes" (Rossinskaia, 2016: 15). Her opinion should be supported that "persons already qualified as a bachelor or specialist in basic maternal sciences are able to acquire the qualifications of a forensic expert in any one type of forensic examination. For 2-2.5 years of master's studies, they may well master the fundamentals of forensic science, substantive and procedural law, expert technologies, and expert research methods for this type of examination. At the same time, the possibility of training forensic experts on new types of forensic examinations in the magistracy based on undergraduate law" (Rossinskaya, 2018: 83).

In addition to the fact that this type of training is not possible in all expert specialties, there are other issues that need to be addressed. So, one of the questions is the determination of the areas of undergraduate or specialty training, after training in which it is possible to continue 
training in an expert specialty in a magistracy. Is it possible to study in a magistracy in an expert specialty, for example, for a bachelor who has studied in the field of preparation 04.03.01 "Chemistry" or 40.03.01 "Jurisprudence"? Do you have to take into account the primary direction of bachelor's studies in preparing the master's program and adjust the curriculum in this regard, and will it be appropriate and in demand by students? Existing regulations do not allow a clear answer. Given the short training period in the magistracy, it is doubtful to obtain deep knowledge in the expert field and in the necessary amount of legal knowledge to carry out expert activities in the specialty.

\section{Conclusion}

Forensic science dictates the need to train qualified expert personnel. The foregoing allows us to conclude that there are several different in form, content, training methods, ways of initial training of forensic experts. None of the existing forms can be considered ideal in achieving the goal of training a competent expert. Each form has inherent disadvantages and advantages. That is why it is simply impossible to deny the existence of any of them today, because otherwise a "personnel" emptiness will form, which is unlikely to be efficiently filled in the shortest possible time.

It seems that each of the forms should be developed, emphasizing and deepening the merits, trying to eliminate the shortcomings. To determine the most optimal form of initial training for a forensic expert, the so-called "subjective" criterion should be applied, the levels and forms of education for people who want to master an expert specialty should be divided depending on the level of their training: an applicant, a bachelor in a non-expert field of training, a judicial expert who wants to receive new expert specialty. So, for persons with basic education (undergraduate) in any field, retraining in the corresponding initial education of an expert specialty on the basis of a university and (or) expert organization may be well suitable. The same form could be effective for existing experts who want to get an additional expert specialty. In addition, for the latter category, including in order to deepen knowledge within the framework of an existing specialty, a master's program in an expert specialty can be effective. For applicants, training in the specialty 40.05.03 "Judicial Expertise" within the framework of the specialty seems to be optimal.

\section{References}

D'iakonova, O.G. (2019). Protsessual'no-pravovoi status sub'ektov primeneniia i ispol'zovaniia spetsial'nykh znanii [Procedural and legal status of subjects of application and use of special knowledge]. Moscow: Publ. Yurlitinform, 400 p. ISBN: 978-5-392-30536-0

Mailis, N.P. (2018). Mailis N.P. O sovershenstvovanii professional'noi podgotovki sudebnykh ekspertov [About improvement of professional training for forensic experts]. In Teoriya i praktika sudebnoi ekspertisy [Theory and Practice of Forensic Science], 13, 2, 50-53.

Grinkevich, T.A. (2017). Organizatsiia professional'noi podgotovki ekspertov v oblasti ekonomicheskikh ekspertiz v Gosudarstvennom komitete sudebnykh ekspertiz Respubliki Belarus' [Organization of professional training for experts in the field of economic expertise in the State Committee of forensic examinations of the Republic of Belarus]. In Pravo i ekonomika: mezhdistsiplinarnye podkhody v nauke i obrazovanii. IV Moskovskii iuridicheskii forum. XII Mezhdunarodnaia nauchno-prakticheskaia konferentsiia (Kutafinskie chteniia): materialy konferentsii $v 4$ chastiakh [Law and Economics: interdisciplinary approaches in science and education. IV Moscow legal forum. XII international scientific and practical conference (Kutafin readings): conference proceedings in 4 parts], Part 3. Moscow: RG-Press, pp. 280-285.

Lapina, I.A. (2018). Podgotovka sudebnykh ekspertov kak odna iz osnovnykh zadach Gosudarstvennogo komiteta sudebnykh ekspertiz [Training for forensic experts as one of the main tasks of the State Committee of forensic examinations]. In Sudebnaya ekspertiza Belarusi [Forensic examination of Belarus], 2 (7), 5-8. 
Smol'kov, P.P., Paramonova, L.F. (2013). Podgotovka ekspertnykh kadrov v Rossiiskoi Federatsii i Respublike Kazakhstan (sravnitel'nyi analiz) [Training for experts in the Russian Federation and the Republic of Kazakhstan (comparative analysis)]. In Materialy 4-i Mezhdunarodnoi nauchno-prakticheskoi konferentsii «Teoriia i praktika sudebnoi ekspertizy v sovremennykh usloviiakh» (g. Moskva, 30-31 ianvaria 2013 g) [Materials of the 4th International scientific and practical conference "Theory and practice of forensic examination in modern conditions" (Moscow, 30-31 January 2013)]. M.: Prospekt, 263-267.

Tamoshiunaite, R. (2018). Podgotovka ekspertov-pocherkovedov v Litovskom tsentre sudebnoi ekspertizy [Training for handwriting experts in the Lithuanian forensic center]. In Aktual'nye problemy reformirovaniia ugolovnoi iustitsii. [Actual problems of criminal justice reform], Odessa, 115-117.

Alyson, Jennifer. Training for Forensic Scientists. available at: http://work.chron.com/training-forensic-scientists-12947.html

Moiseeva, T.F. (2019). Unifikatsiia podgotovki sudebnykh ekspertov kak neobkhodimoe uslovie mezhdunarodnoi integratsii sudebno-ekspertnoi deiatel'nosti [Unification of training for forensic experts as a necessary condition for international integration of forensic activities]. In Kriminalistika i sudebnaia ekspertologiia: nauka, obuchenie, praktika [Forensics and forensic science: science, training, practice]. II. Kaunas, 421-428.

Rossinskaya, E.R. (2018). Aktual'nye problemy podgotovki sudebnykh ekspertov i dopolnitel'nogo obrazovaniia po otdel'nym ekspertnym spetsial'nostiam [Actual problems of training for forensic experts and additional education in certain expert specialties]. In Teoriya i praktika sudebnoi ekspertisy [Theory and Practice of Forensic Science], 13, 3, 78-85.

Toropova, M.V. (2017). K voprosu ob organizatsii dopolnitel'nogo professional'nogo obrazovaniia rabotnikov sistemy sudebno-ekspertnykh uchrezhdenii Miniusta Rossii [On the issue of organization of additional professional education of employees of the system of forensic institutions of the Ministry of justice of the Russian Federation]. In Teoriya i praktika sudebnoi ekspertisy [Theory and Practice of Forensic Science], 12, 1, 15-21.

Kaverina, E.Iu. (2019). Novyi format podgotovki sudebnykh ekspertov-ekonomistov: aktual'nye voprosy i resheniia [New format of training for forensic experts-economists: topical issues and solutions]. In Teoriia i praktika sudebnoi ekspertizy v sovremennykh usloviiakh: materialy VII Mezhdunarodnoi nauchno-prakticheskoi konferentsii [Theory and practice of forensic examination in modern conditions: proceedings of the VII International scientific and practical conference]. Moscow: RG-Press, 184-190.

Ivanova, E.V., D'iakonova, O.G. (2018). Formy podgotovki sudebnykh ekspertov na postsovetskom prostranstve [Forms of training forensic experts in the post-soviet space]. In Istoriia i sovremennost' sudebno-ekspertnogo obrazovaniia: Materialy Mezhdunarodnoi nauchno-prakticheskoi konferentsii, posviashchennoi 15-letiiu obrazovaniia Instituta povysheniia kvalifikatsii i perepodgotovki kadrov Gosudarstvennogo komiteta sudebnykh ekspertiz Respubliki Belarus' (Minsk, 25-26 oktiabria 2018 g.) [History and modernity of forensic education: Materials of the International Scientific and Practical Conference dedicated to the 15th anniversary of the Institute for Advanced Studies and Retraining of the State Committee of Forensic Examinations of the Republic of Belarus (Minsk, October 25-26, 2018.)]. Minsk, 86-90.

Neretina, N.S. (2017). Metodicheskie problemy proizvodstva novykh rodov i vidov sudebnykh ekspertiz [Methodical problems of production of new genera and types of forensic examinations]. In Sovremennaia nauka [Modern science], 8, 1-3, 66-73.

Usov, A.I. (2015). Sovremennye modeli obucheniia sudebnykh ekspertov kak osnova kadrovogo obespecheniia sudebno-ekspertnoi deiatel'nosti v Evrazii-skom ekonomicheskom soiuze [Modern models of training of forensic experts as the basis of staffing forensic activities in the Eurasian economic Union]. In Teoriya i praktika sudebnoi ekspertisy [Theory and Practice of Forensic Science], 4 (40), 20-25.

Smirnova, S.A. (2018). Sudebnaia ekspertiza kak bazovyi mekhanizm realizatsii printsipa verkhovenstva prava $\mathrm{v}$ gosudarstvakh - chlenakh SHOS [Forensic examination as a basic mechanism for the implementation of the principle of the rule of law in the member States of the Shanghai cooperation organization]. In Teoriya i praktika sudebnoi ekspertisy [Theory and Practice of Forensic Science], 13, 2, 6-15. 
Rossinskaya, E.R. (2016). Federal'nye gosudarstvennye obrazovatel'nye standarty 3-ego pokoleniia i podgotovka sudebno-ekspertnykh kadrov v Rossii [Federal state educational standards of the 3rd generation and training of the forensic personnel in Russian Federation]. In Pravo i gosudarstvo. Zhurnal Universiteta KAZGIUU [Law and the State. Journal of KAZGUU University], 1 (70), 12-15.

U.S. Department of Justice, Office of Justice Programs, National Institute of Justice. REPORT: Education and Training in Forensic Science: A Guide for Forensic Science Laboratories, Educational Institutions, and Students. Available at: https://www.ncjrs.gov/pdffiles1/nij/203099.pdf

\title{
Современные направления первоначальной подготовки судебных экспертов
}

\author{
О.Г. Дьяконова
}

Московский государственный юридический университет

им. О. Е. Кутафина

Российская Федерачия, Москва

\begin{abstract}
Аннотация. Практически ни один вид судопроизводства не обходится без привлечения экспертов для производства экспертного исследования или специалистов для консультации. В этой связи весьма остро встает вопрос определения компетентности этих субъектов лицами, ведущими процесс, не обладающими специальными знаниями в той области, в которой специализируется сведущее лицо. Автором определяется компетентность судебного эксперта и перечисляются иные требования к эксперту как участнику судопроизводства. На формирование компетентности в первую очередь влияет уровень подготовки, образование эксперта или специалиста. Основное внимание уделяется раскрытию основных путей первоначальной подготовки и переподготовки судебных экспертов на современном этапе: традиционный путь подготовки экспертов; специалитет по специальности «Судебная экспертиза»; магистратура по программам экспертных специальностей. Анализируются существующие виды подготовки и переподготовки судебных экспертов в России и некоторых зарубежных странах, в том числе странах - участницах Евразийского экономического союза (ЕАЭС). Традиционный путь подготовки судебных экспертов и обучение по программе специалитета раскрываются исходя из исторической обусловленности и необходимости подготовки специалистов для осуществления судебно-экспертной деятельности. Выделяются позитивные и негативные черты направлений подготовки с учетом их влияния на формирование компетентности судебного эксперта. Автор подчеркивает необходимость развития существующих форм первоначальной подготовки судебных экспертов с учетом достоинств и недостатков каждой из них. Сделан вывод о необходимости применения субъектного критерия в целях определения эффективной формы подготовки судебных экспертов.
\end{abstract}

Ключевые слова: подготовка экспертов, переподготовка экспертов, высшее образование, судебная экспертиза, использование специальных знаний.

Научная специальность: 12.00.12 - криминалистика, судебно-экспертная деятельность, оперативно-розыскная деятельность. 